\title{
STRENGTHENING OF SOCIAL COMPETENCY THROUGH LEARNING INDEPENDENCE OF ISLAMIC EDUCATION OF RECIPROCAL TEACHING MODElS WiTh METACOGNITIVE APPROACH OF PRIMARY SCHOOL STUDENTS
}

\author{
Ahmad Yani T. ${ }^{1)}$, Misdah ${ }^{2)}$, Wahab ${ }^{3)}$ \\ ${ }^{1)}$ Universitas Tanjungpura, Pontianak, Indonesia \\ E-mail: ahmad.yani.t@fkip.untan.ac.id \\ ${ }^{2)}$ IAIN Pontianak, Pontianak, Indonesia \\ E-mail:misdahjamani@gmail.com \\ ${ }^{3)}$ IAIN Pontianak, Pontianak, Indonesia \\ E-mail:abdulwahabassambasi@gmail.com
}

\begin{abstract}
This study aims to obtain empirical evidence on strengthening social competence (Islamic Studies subjects; Arabic script) through the independent learning of reciprocal teaching models with a metacognitive approach. The population in this study was the fifth-grade students of SD Mujahidin Pontianak City. While the sample was taken randomly from two classes from 5A and 5C to class 5 students. One class received Reciprocal Teaching (RT) model learning with a metacognitive approach as an experimental group and one class received regular learning as a control group. The instruments used in this study consisted of three types of instruments, namely: (1) observation sheets, (2) students' independent learning scales, and (3) learning outcomes tests on Islamic Education subjects. Based on the data analysis in this study, the process of strengthening social competence through student learning independence in the subject of Islamic Religious Education uses the reciprocal teaching model with a metacognitive approach practiced at SD Mujahidin Pontianak can be seen from the main component of learning (core competence). Efforts to strengthen social competence through independence can be designed through a Reciprocal Teaching model with a metacognitive approach gradually and intact. The first process starts with the development of the lesson plan as an operational design in the practice of Islamic Education learning. Development of learning components in the lesson plan, namely materials, methods, media, sources, and evaluation that are more creative, innovative. The teaching of teaching materials as a whole, which includes cognitive, affective, and psychomotor teaching materials. Second, there are differences in strengthening social competence through independent learning between students learning Islamic education using the reciprocal teaching model with a metacognitive approach and students learning Islamic education using ordinary learning models. The independent learning of students in Islamic Religious Education in the group that received reciprocal teaching model learning with a metacognitive approach was better than the control group.
\end{abstract}

Keywords: Learning Independence; Islamic Education; Strengthening Social Competence

\section{INTRODUCTION}

Islamic education to achieve equality in the growth of human individuality as a whole uses ways to train the human soul, mind, feelings, and physique (Sukino, 2013: 5). Islamic education is a procedure of giving directions based on the Qur'an and Sunnah. This command aims to carry out Allah's commands through the Qur'an. As Allah SWT said which means: "O you who believe, enter into Islam completely and do not follow the steps of Satan, actually Satan is a real enemy to you" (Surah Al-Baqarah: 208). This shows that Shaytan does not want believers to convert to Islam in an orderly manner, both in terms of faith, worship, and behavior (noble morals). To be able to carry out and live up to religious 
teachings ("Core competence 1 or spiritual competence") as stated in the lesson plan for each subject from primary and secondary education, social competence is needed. Because social competence or Core II competencies contain values that must be possessed by every student. The values that need to be reinforced include honesty, responsibility, discipline, fairness, and cooperation. Strengthening social competence provided through independent learning to equip students to become human beings with noble character. The reality in these schools only provides a measurable strengthening of cognitive and psycho-motor competencies, while strengthening social competence has not been completely implemented both in the learning process and in school activities (Visi-Misi SD Mujahidin, 2019).

In Ibn Kathir's Tafsir (2009: 405) explains that Allah Ta'ala instructs His servants who believe in Him and testify to His Messenger, to be guided by all the ropes of Islam and its shari'ah, carry out His commands, along with avoiding all His prohibitions with all your might. In other words, fulfill all righteous deeds and various types of policies. To be able to carry out the orders of Allah SWT and Sunnah, it is necessary to understand the Risalah brought by the Prophet Muhammad, so that he can become a knowledgeable person, have a very pure heart, has a simple appearance, and are very honest in speaking (Tafsir Ibnu Katsir, 2009: 301).

The theme of curriculum development in 2013 is to create a productive, creative, innovative Indonesian personality, by strengthening integrity in behavior, skills, and knowledge to give birth to a creative Indonesian personality. Creativity is a driving force for innovation without innovation creativity is just an idea. If creative individuals do not generate new ideas, then innovation will not exist. (Suharsaputra, 2016: 272). Contents in the curriculum are some of the skills and one of the skills that must be understood is metacognitive intelligence (Ramadhan, 2018: 2). This matter is related to Core 3 competency, which is "mastering, practicing and studying authentic, conceptual, procedural, and metacognitive knowledge based on his curiosity about technological knowledge, statehood, civilization which is linked to triggers of phenomena and events in the field of work specifically for solving problems" (Ministry of Education and Culture, 2013: 10).

In the educational process, the use of metacognitive skills is not only in mathematics and science subjects but also in Islamic education and Civics. The application of PAI has many obstacles and weaknesses. This weakness is caused because the application of education only looks at a cognitive point of view only from the development of understanding the values (religion) and ignores the development of effective and conservative aspects, namely the desire and determination to practice the values of religious teachings (Muhaimin, 2007: 23).

The Ministry of Education and Culture (2017: 3) stated that one of the goals of Islamic Religious Education (PAI) is to make Indonesian people who are religiously obedient and have good manners by promoting exemplary behavior in being honest, disciplined, responsible, and patient, personally and socially in life. Based on these observations at school there are still students who have not practiced and carried out Islamic religious activities as they should, namely praying in congregation, lazy to give alms, throwing garbage out of place, there is also late entering school and collecting assignments. Therefore, there needs to be an effort to overcome this problem by strengthening social competence. In each subject, social competence is already in the lesson plan. If this cannot be secured for students, it can result in a moral crisis which can be fatal.

In learning Islamic education in schools, the most important issue that exists is that the condition of the curriculum itself should be innovated or even reformed openly to suit the dynamics of the discourse and its time (Armai, 2019: 5). Because the curriculum is one of the components that are very sure in a learning system (Sukino, 2013: 8). This needs to strengthen students' social competence related to aqidah, fiqh, and morals. For example, the story of Lukman teaching his son in Surah Lukman verses 12 to 19, which explains the principles of educational material consisting of issues of faith, morals, worship, social and science (Sukino, 2013: 31). To give birth to children who are not disobedient (Syarif, 2014: 7).

In using the reverse learning model and the metacognitive approach, it can be applied in elementary schools and has a positive impact (Ritonga, 2008; Saragih, 2017). Therefore, this research was conducted to strengthen the social competence of elementary school students in Islamic religious education through independent learning using the reciprocal teaching model and the metacognitive approach. The use of the reciprocal teaching model and the metacognitive approach to reinforce social competence because the steps in the model show a hierarchy of abilities based on awareness of motivation in solving problems.

By paying attention to the above problems, it is hoped that the PAI teacher's job can develop social competence. Because social competence has a meaningful function for social growth, a person can express social attention more, is sympathetic, kind, let alone prefers to help. Thus social competence is a person's expertise in collaborating, building social interaction with the surrounding area by using knowledge about himself, and being skilled and able to speak well with a sense of empathy. 3 aspects affect social competence, namely cognitive (knowledge), ties with family, and personality (Calhoun, 1995). Moreover, there is a positive relationship between a person's personality and social competence (Marheni, 1998).

Therefore, the process of Islamic education in schools is focused on strengthening social competence through independent learning with a reciprocal teaching model using a metacognitive approach. With the hope that it can strengthen social competences and procedures that are innovative and fun.

\section{LITERATURE REVIEW}

\section{A. Strengthening Social Competence through Independent Learning}

Strengthening an educator's effort to secure, stabilize, and convince certain things that exist in students. Competencies in 
the 2013 revised 2017 curriculum include critical thinking/problem solving, creativity, communication, collaboration. Meanwhile, strengthening social competence is the readiness of students to do work either individually or collectively and to be able to build social interactions with the surrounding environment according to their knowledge and skill in communicating well with a sense of empathy (Mahendra, 2013: 18). For indicators of strengthening social competence through independent learning. Learning independence in this study consists of:(1) have seriousness in learning, (2) can identify learning needs, (3) have clear learning objectives that can be realized (4) use learning time regularly, (5) are full of patience in solving problems, (6) can complete tasks by searching for relevant sources, (7) can choose the right one in learning, (8) control the learning process and outcomes, and (9) have self-confidence (Reni, 2010).

\section{B. The Importance of Social Competence for Teachers and Students}

It is almost certain that the challenge for teachers is getting tougher, because of the changing times in the digital era. Because the teacher's job as a teacher and educator is influenced, there are social media and the internet that can be accessed by all people. This makes it difficult for teachers and parents to instill social ethics and noble morals. Even though the roles of parents and teachers have the most important function to create honest, disciplined, hard-working, modest, responsible students (Supardan, 2011: 315). To overcome this, teachers as educators are equipped with "social competence". Social competence is fostered through a series of interactions that emphasize the importance of the meaning of living together (Suryadi, 2011: 312).

Based on the Regulation of the Minister of National Education No. 16 of 2007 states that the indicators of social competence are as follows:

1. Be honest, patient, disciplined, responsible, cooperative, tolerant.

2. Communicating politely with intentions towards students

3. Can adapt to work with socio-cultural diversity.

4. Can communicate both verbally and non verbally with the professional community itself or other professions.

Efforts to grow and provide strengthening of social competence are carried out through various possible approaches and activities. One of the activities that provide the most hope is through learning activities that can be managed by professional teachers. The PPG teaching materials (2019: 7) stated that social competence is an important element that must be owned by a professional educator who is always dealing with and interacting with students (humans). This competence can be seen from the behavior according to the indicators, namely: (a) being inclusive of school members, (b) having the ability to communicate well (verbal and non-verbal), (c) having the ability to adapt well in the workplace.

\section{Strengthening Social Competence in Islamic Religious Education}

Learning is defined as a process or way of making people learn (Depdiknas, 2000). There are several terms related to the word learning (instruction), namely an instructor, or a person who learns is called a student. The term learning is defined as a process that is carried out by a person in obtaining learning, and the term learning in the context of learning is defined as a learning activity carried out by a person (student) to obtain knowledge, values, and attitudes on an ongoing basis after he/she has learned.

According to Al Abrasy (1980: 79-80) stated that the basic basics of Islamic religious education are as follows.

\section{1) Education of faith in Allah SWT}

God's Word:

"Remember, only Allah belongs to a clean religion (from shirk)" (Surah Az-Zumar: 3). Then "And worship your Lord until faith comes to you." (Surah Al-Hijr: 99). Social competence that contains many universal values, for example, honesty, patience, cooperation which is part of the faith instilled in students, is a manifestation of attitudes and behavior towards Allah, including spiritual attitudes, aspects of aqidah, worship, and morals (Muhtadi, 2020: 9).

In "theory" or normative aspects of the values of aqidah and morals to Allah in elementary schools are given through the subject matter of aqidah and morals, the Qur'an, hadith, and fiqh. For the application of material cultivation of aqidah and morals and worship, it can be done by providing classroom learning, through habituation, and the role of teachers. Based on school students responding to a rule or values is easier to do in activity through dialogical methods, or discussion. Because students in learning are more fun to practice directly, for example: in ablution, prayer, Qur'an, charity. This shows the very importance of forming a belief in Allah SWT which will form the basis of behavior, attitudes, and personality.

\section{2) Good moral education}

To be able to obtain a basis of belief or faith, efforts are needed to form noble morals. According to Abdullah bin Muhammad ar-Razy (in Al-Qusyairy An-Naisabury, 2006: 291) stated that "morality means exalting that which comes from Allah. Allah said: "And indeed you have great morals (Qs Al-Qalam: 4). Anas bin Malik RA: "O Messenger of Allah, who among the believers has the most faith?" $\mathrm{He}$ answered: "Namely those who are the best in character". Moral education is a principle and learning process that humanizes humans to become good citizens, citizens, and citizens of the world. Therefore, moral education develops all good potentials (adab) which are the mental needs of humans (mental needs) such as spiritual, social (affective), knowledge (cognitive), and skills (skills). With that capital, humans act/behave in accordance with the standards of behavior based on religious values and norms in society. Islamic education in the concept of PAI is directed at personality education, education that humanizes humans forms human identity as individuals, social beings, part of nature, and Al Khalik's creatures who believe and devote themselves to Him. 


\section{3) Worship Education}

Worship (etymology) of confession along to humble oneself and obey. Meanwhile, according to syara '(terminology), worship is a designation that includes all that is loved and blessed by Allah Azza wa Jalla, both in the form of words or deeds, both zahir and inner (Yazid, 2005). In the application of SD, worship education is carried out through the following activities.

a) Implementation of the noon prayer in the congregation of students in grades 3,4,5 and 6 .

b) Fast Islamic boarding school activities at the beginning of the fasting month of Ramadan

c) Hajj

d) Social service to help the poor.

Therefore, this educational process emphasizes the appreciation and practice of Islamic teachings or values. The approach is carried out through prayer activities and activities to commemorate Islamic holidays. This activity is to provide strengthening social competence for students to communicate and collaborate. Thus, friendship is established to create student social solidarity.

To develop students' knowledge skills, activities are carried out through: (a) an honest canteen, (b) providing a place to store lost items, (c) maintaining cleanliness of the environment, (d) visiting friends who are sick, (e) slaughtering sacrificial animals, (f) helping or donating a sick friend, (g) adding PAI lessons.

\section{Reciprocal Teaching Model and Metacognitive Approach}

\section{1) Reciprocal Teaching Model}

The reciprocal teaching model was originally raised by Palinscar and Brown (1984) who reported that "reciprocal teaching" is an educational procedure designed to enhance students' descriptions and reasoning of teaching materials. As for the steps for the reciprocal teaching strategy with groups, they are as follows :

a. Make students in groups of 4 people

b. Give a notecard to each group member to make a summary, problem, explain, and predict.

c. Instruct students to make notes from teaching materials.

d. Students are tasked with summarizing, compiling, explaining, and predicting.

e. Present by showing group representatives.

\section{2) Metacognitive Approach}

Metacognitive is a designation that comes from the word metacognitive character. Metacognition has 2 words, namely meta, and cognition. Meta means after or beyond and cognition means skills related to thinking processes. The ability to process thinking based on motivation and awareness appropriately. Nindiasari (2004) cognitive strategies that use the process of thinking are intellectual skills that are properly carried out according to procedures in answering and completing questions. conversely metacognitive cognitive strategies are controlling all learning activities, if necessary, modify the strategies used to achieve goals. Application in learning children ask themselves to test their understanding of the material being studied. These metacognitive activities arise through 4 situations, namely: (1) The students are asked to justify, (2) the cognitive atmosphere in experiencing a problem opens the opportunity to formulate problems, (3) the student participants are asked to make a summary and record words or statements that have not been understood.

\section{METHODOLOGY}

This research is a form of experimental designs for practicing a reciprocal teaching model with a metacognitive approach to strengthening the social competence of students in learning Islamic education. Experimental research procedures can be referred to as research procedures used to seek the influence (strengthening) of certain treatments against others in controlled conditions (Sugiyono, 2015: 107). The experimental research design aims to strengthen social competence through independent Islamic education learning using the reciprocal teaching model with a metacognitive approach for the fifth-grade students of SD Mujahidin, Pontianak City, which consists of 5 classes, but as a sample of class $5 \mathrm{~A}$ is 40 students. In contrast, the control group was given conventional learning treatment. By distributing different treatments between the experimental group and the control group, We want to obtain data that describes the existence of a comparison of strengthening social competence through independent learning with a metacognitive approach. The data collection tools used the PAI learning independence scale, learning outcomes test, and social competency observation sheets.

\section{RESULTS AND DISCUSSION}

The learning outcome test was given to students in class $\mathrm{V}$ SD Mujahidin Pontianak as the control class as many as 40 people and the experimental class as many as 40 people. The learning process in the two classes is each given a different learning model. The experimental class using the reciprocal teaching model with a metacognitive approach and the control class using a conventional model. At the end of the second lesson, the two classes were given a learning outcome test.

The results of the test results of student learning outcomes who were given treatment in the form of learning with a reciprocal teaching model with a metacognitive approach, namely the experimental class with students learning Islamic Education using conventional learning models in the control class can be seen in Table I.

TABLE I

RECAPITULATION OF CONTROL AND EXPERIMENTAL CLASS LEARNING TEST RESULTS

\begin{tabular}{lccccc}
\hline \multicolumn{1}{c}{ Class } & $\begin{array}{c}\text { Ideal } \\
\text { Score }\end{array}$ & Average $\begin{array}{c}\text { Score- } \\
\text { Min }\end{array}$ & $\begin{array}{c}\text { Score- } \\
\text { Max }\end{array}$ & Percentage \\
\hline Control & 90 & 74.0 & 69 & 81 & $82.2 \%$ \\
Experiment & 90 & 78.1 & 75 & 84 & $86.8 \%$ \\
\hline
\end{tabular}

In Table I, information/data is obtained that students' learning outcomes in the control class have an average 
percentage of $82.2 \%$ and are in the high category while in the experimental class after being given treatment through learning with the Reciprocal Teaching model with a metacognitive approach has a percentage of $86.8 \%$ and belong to the high category. This shows that there is an increase of $4.6 \%$ in the experimental class that was given treatment in the form of learning with the reciprocal teaching model with a metacognitive approach.

\section{A. Results of the Student Learning Independence Questionnaire}

The student learning independence scale was given to the two treatment groups, namely the experimental group and the control group. Actually, this scale is given to determine the independent learning of fifth-grade elementary school students in learning Islamic education. The PAI student learning independence scale consists of 50 statements consisting of 25 favorable statements and 25 unfavorable statements. Aspects that are measured from the student learning independence scale in PAI are nine indicators. The results of the calculation of the scale score and the neutral score of the students' learning independence in the Islamic Religious Education subject in the two research classes, it is shown in Table II.

\section{TABLE II}

RECAPITULATION OF STUDENT LEARNING INDEPENDENCE QUESTIONNAIRE SCORES

\begin{tabular}{|c|c|c|c|c|c|}
\hline \multirow{2}{*}{ No. } & \multirow{2}{*}{ Aspect } & \multicolumn{2}{|c|}{ Neutral Score } & \multicolumn{2}{|c|}{ Scale Score } \\
\hline & & Experime & Control & Experiment & Control \\
\hline 1 & Learning initiatives & 3.15 & 3.18 & 3.05 & 2.99 \\
\hline 2 & $\begin{array}{l}\text { Diagnosing learning } \\
\text { needs }\end{array}$ & 3.20 & 3.65 & 2.88 & 2.58 \\
\hline 3 & Set learning goals & 2.60 & 3.25 & 3.48 & 2.99 \\
\hline 4 & $\begin{array}{l}\text { Monitor, organize and } \\
\text { control learning }\end{array}$ & 3.04 & 2.98 & 3.45 & 2.93 \\
\hline 5 & $\begin{array}{l}\text { View adversity as a } \\
\text { challenge }\end{array}$ & 2.96 & 3.35 & 3.52 & 2.85 \\
\hline 6 & $\begin{array}{l}\text { Make use of and look } \\
\text { for relevant learning } \\
\text { resources }\end{array}$ & 2.96 & 3.05 & 3.88 & 2.78 \\
\hline 7 & $\begin{array}{l}\text { Choosing and } \\
\text { implementing learning } \\
\text { strategies }\end{array}$ & 2.96 & 3.15 & 4.16 & 2.99 \\
\hline 8 & $\begin{array}{l}\text { Evaluating the process } \\
\text { and learning outcomes }\end{array}$ & 3.15 & 2.65 & 4.22 & 2.86 \\
\hline 9 & Self concept & 3.65 & 3.25 & 4.25 & 2.78 \\
\hline & Average & 3.06 & 3.15 & 3.67 & 2.86 \\
\hline
\end{tabular}

From Table II, it shows that the experimental group students have positive learning independence in Islamic Religious Education (PAI). This can be seen from almost all aspects of learning independence, the scale score is greater than the neutral score, especially for the third, sixth, seventh, eighth, and ninth aspects, where the difference in the scores of the two is very large. However, this did not happen in the first and second aspects or indicators, in the first aspect the scale score was 3.05 which was smaller than the neutral score which the average was 3.15 . In the second aspect, the scale score is 2.88 smaller than the neutral score is 3.20 . This means that students' independent learning in learning initiatives and diagnosing PAI learning needs is still lacking or is responded negatively by the experimental group students.

Conversely, this did not happen in the control group, because almost all aspects of learning independence that would be measured were responded negatively by the students. This can be seen from the mean score and almost all aspects whose opinion scale score is less than the neutral score. There is only one aspect that has responded positively, namely the eighth aspect, which means that students are very positive in evaluating the process and learning outcomes. This is based on his scale score of 2.86 which is greater than his neutral score of 2.65. When viewed from the two scores both on the opinion scale score and on the neutral score the difference is very small so that many of the statements on the student learning independence scale were responded positively by the control group students. So basically the control group students also responded positively to the students' learning independence scale in Islamic Education subjects. So in general it can be concluded that the control group students' learning independence is still lacking. If we look at the comparison of the mean score of the opinion scale of the two treatment groups, it is very much different, because all aspects of the student's learning independence, the experimental group's opinion scale score are 3.67 greater than the control group which means 2.86 .

\section{B. Students Social Competency Questionnaire Results}

Along with the increase in student test results, social competence through student learning independence has also increased. PAI learning using the reciprocal teaching model with a metacognitive approach shows positive results in strengthening students' social competencies. The average percentage of students 'social competence strengthening in the control class was $92.48 \%$, then in the experimental class, the average percentage of students' social competence was $94.53 \%$. The results of increasing the social competence of students in the control class and experimental class are more clearly seen as in Fig. 1.

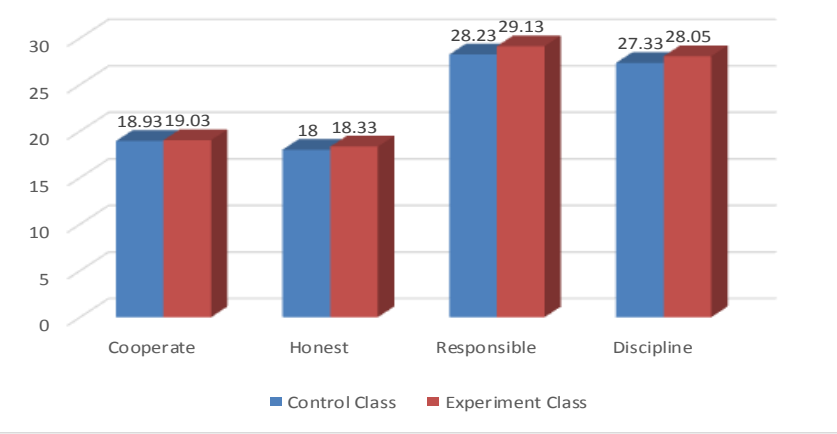

Fig. 1 Enhancement of social competency questionnaire results

To improve the strengthening of students' social competence, one of which is by implementing the Reciprocal Teaching-learning model with a metacognitive approach, thus 
increasing the social competence of students, namely an average of 94.53 .

\section{Reciprocal Teaching Model with Metacognitive Approach}

Based on the results of observations that were tried on groups using the reciprocal teaching model with a metacognitive approach, which increases activity and can provide enthusiasm in solving the problems given. The quality of the learning process activities from the observations tends to increase at each meeting. At the initial and second meetings, student activities tended to be in adjustment sessions with the newly accepted models.

This model shows students are more active, creative, and courageous in the learning process in class. The students' courage to explain or write down the results of the dialogue in front of the class was also very good. In teaching and learning activities in the classroom, the aspect of time management has a low average. This is due to the difficulty that researchers feel like teachers in getting used to and managing time, especially when students have a good discussion filling out the worksheets and explaining the results of the dialogue in front of the class. Conversely, in the aspect of student activity, the low average is the activeness of students in answering or submitting comments. Universally, the reciprocal teaching model process activities with a metacognitive approach are good and very positive.

\section{CONCLUSIONS}

The process of strengthening student social competence in the subject of Islamic Religious Education in elementary schools could be done through independent learning with the reciprocal teaching model and the metacognitive approach had shown differences in control and experimental classes. Strengthening students' social competence in the students' experiment were accustomed to working together in doing assignments, being honest, being responsible for assignments, and being disciplined in collecting according to schedule.

\section{REFERENCES}

Abdullah bin Muhammad bin "Abdurrahman bin Ishaq Alu Syaikh. (2009). Tafsir Ibnu Katsir, jilid 1, Cetakan ketujuh, Terjemahan, Bogor: Pustaka Iman Syafi'i.

Armai, A. (2019). Paradigma Pendidikan Agama Islam. Bahan Ajar Perkuliahan S2 PAI IAIN Pontianak.

Calhoun, L. (1995). The Philosophy of Discreditation An Essay On Actuality And Possibility. Journal of Social Philosophy, 26(2). 66-72.

Kemendikbud. (2013). Kerangka Dasar dan Struktur Kurikulum Sekolah Menengah kejuruan/Madrasah Aliyah kejuruan. Jakarta: Kemendikbud.

Kemendikbud. (2017). Model Silabus Mata Pelajaran Sekolah Menengah Pertama/Madrasah Tsanawiyah (SMP/MTs). Jakarta: Kemendikbud.

Mahendra, B.S. (2013). Hubungan antara kompetensi sosial dengan prestasi Akademik pelajaran sosiologi tahun pertama pada siswa MA Mamba'ul Ulum Desa Awang-Awang Kecamatan Mojosari Kabupaten
Mojokerto. Universitas Islam Negeri Maulana Malik Ibrahim, Retrieved from http://etheses. UinMalang.ac.id./1824/

Marheni, A. (1998). Hubungan Antara Temperamen dan Inteligensi dengan Kompetensi Sosial Anak. Tesis (tidak diterbitkan). Yogyakarta: Program Pasca Sarjana UGM.

Muhaimin. (2007). Pengembangan Kurikulm Pendidikan Agama Islam. Jakarta: PT. Raja grafindo.

Muhtadi, A. (2020). Penanaman Nilai-Nilai Agama Islam Dalam Pembentukan Sikap Dan Perilaku Siswa Sekolah Dasar Islam Terpadu Luqman Al-Hakim Yogjakarta. Jurnal Prodi Teknologi Pendidikan FIP UNY.

Ramadhan, R.M. (2018). Tingkat Metakognitif Siswa Dalam Pembelajaran Pendidikan Agama Islam Berbasis Masalah. Studi Kasus di SDN Kendangsari I dan II Surabaya). Tesis. Surabaya: Pascasarjana Universitas Islam Negeri Sunan Ampel. (Unpublished).

Reni A. (2009). Studi Perbandingan Kemampuan Komunikasi Matematik Dan Kemandirian Belajar Siswa Pada Kelompok Siswa Yang Belajar Reciprocal Teaching Dengan Pendekatan Metakognitif Dan Kelompok Siswa Yang Belajar Dengan Pembelajaran Biasa. Tesis. Program Studi Pendidikan Matematika Sekolah Pasca Sarjana Universitas Pendidikan Indonesia. (Unpublished).

Sugiyono. (2015). Metode Penelitian Kombinasi (Mix Methods). Bandung: Alfabeta.

Suharsaputra, Uhar. (2016). Metode Penelitian Kuantitatif, Kualitatif, dan Tindakan. Bandung: PT Refika Aditama.

Sukino, A. (2013). Ilmu Pendidikan Islam. Pontianak: STAIN Pontianak Press.

Supardan, D. (2011). Mengintif Bahaya Kekerasan Sebagai Acaman Pendidikan Karakter Bangsa: Anatomi Perspektif Ilmu-Ilmu Sosial. In "Pendidikan karakter: nilai inti bagi upaya pembinaan kepribadian bangsa". Bandung: Widya Aksara Press.

Suryadi, K. (2011). Kompetensi Sosial Masyarakat Majemuk Modal Sosial Untuk Membangun Karakter Bangsa. In "Pendidikan karakter: nilai inti bagi upaya pembinaan kepribadian bangsa". Bandung: Widya Aksara Press.

Syarif. (2014). Wujud di Balik Teks, Studi Al-Quran dengan Pendekatan Hikmah. Bandung: Nusa Media. 